\title{
STUDY KINETIKA REAKSI EKSTRAK BUAH TOMAT DALAM PENYEMBUAHAN SEMBELIT
}

\author{
Reni Perwasih ${ }^{* 1}$ \\ ${ }^{1}$ Pendidikan Kimia,FMIPA, Universitas Negeri Padang, Indonesia \\ *E-mail : reniperwasih03@gmail.com
}

\begin{abstract}
Abstrak. Studi ini bertujuan untuk membuat ekstrak buah tomat sebagai pencegah sembelit dan diare. Metode yang digunakan adalah eksperimen dan uji aktivitas katalitik secara langsung. Tahapan pertama dilakukan dengan pembuatan ekstrak dari buah tomat. Uji aktivitas langsung dengan variasi satu gelas $200 \mathrm{~mL}$ sebelum tidur, satu gelas $200 \mathrm{~mL}$ pada pagi dan sore hari, dan satu gelas $200 \mathrm{~mL}$ setelah makan selama 3 hari pemakaian. Hasil eksperimen membuktikan bahwa ekstrak tomat dapat menyembuhkan penyakit sembelit . Kondisi optimum pemakaian ekstrak tercapai pada pemakaian sebanyak 2 kali sehari yaitu pada pagi dan sore hari selama 3 hari. Penyembuhan sembelit diduga karena aktivitas katalitik ekstrak buah tomat terhadap gerakan peristaltik sistem pencernaan pada usus oleh serat yang terkandung dalam buah tomat matang atau merah.
\end{abstract}

Keywords: Katalitik, ekstrak, buah tomat, sembelit, serat

\section{Pendahuluan}

Aktivitas katalitik merupakan suatu aktivitas dimana dapat mempercepat atau memperlambat laju suatu reaksi kimia(1). Penggunaan katalitik ini ditujukan kepada keinginan pengguna, apakah ingin mempercepat suatu laju reaksi atau memperlambat suatu laju reaksi(2). Reaksi kimia merupakan suatu reaksi antara suatu senyawa dengan senyawa lainnya yang nantinya menghasilkan suatu produk yang diinginkan(3). Di mana produk yang dihasilkan ini memiliki sifat yang berbeda dengan senyawa asalnya(4). Reaksi kimia terdapat sangat banyak di sekitar kita baik di lingkungan maupun di dalam tubuh kita sendiri. Reaksi kimia di dalam tubuh dapat seperti proses metabolisme dalam tubuh(5). Sebagai contoh dalam proses pencernaan makanan menjadi sari-sari makanan oleh enzim-enzim yang ada di dalam tubuh kita(6).

Suatu reaksi kimia memberikan ciri-ciri di antaranya terjadinya perubahan suhu, terbentuknya suatu endapan, adanya gas sebagai hasil reaksi, dan lain-lain(7). Suatu reaksi kimia dapat berlangsung lambat dan cepat, bahkan ada yang berlangsung sangat lambat(8). Hal ini tergantung pada kondisi di saat reaksi itu terjadi. Dalam hal ini maka aktivitas katalitik dapat berperan sebagai mempercepat atau memperlambat laju reaksi tersebut(9). Dalam proses pencernaan makanan, terjadi proses perombakan sumber energi dari bahan-bahan makanan menjadi energi yang dapat dipergunakan oleh tubuh untuk melakukan segala aktivitas. Baik aktivitas di luar tubuh maupun aktivitas di dalam tubuh itu sendiri(10).

Suatu proses pencernaan sangat penting dalam tubuh, di mana melalui proses ini tubuh mendapatkan sumber energi. Suatu proses pencernaan ada yang lancar dan ada yang kurang lancar 
bahkan mengelami gangguan yang serius(11). Seperti terjadinya gangguan pada otot-otot pada sistem pencernaan yang mengakibatkan gerakan peristaltik terganggu(12). Gerakan peristaltik itu sendiri merupakan gerakan menelan atau mendorong makanan sehingga dapat dicerna oleh enzim dengan mudah(13). Terganggunya gerakan peristaltik ini dapat menyebabkan terjadinya beberapa penyakit seperti sembelit. Sembelit yaitu susah buang air besar yang disebabkan oleh beberapa hal(14). Sembelit merupakan suatu penyakit yang sangat umum di kalangan masyarakat. Sembelit sudah tidak asing lagi didengar bahkan dalam masyarakat awam(15).

Sembelit ini terjadi karena adanya kegagalan dalam proses pencernaan dalam usus. Kegagalan dalam mencerna makanan ini dapat dikarenakan oleh beberapa hal seperti makanan yang di konsumsi, banyak pikiran atau stres, perbedaan lingkungan dan masih banyak yang lainnya(16). Sembelit dapat juga disebabkan karena kurangnya konsumsi terhadap serat . Dalam penyembuhannya masyarakat sekarang memilih jalan yang efisien dan cepat yaitu dengan mengonsumsi obat-obat yang dijual di pasaran dan apotek(17). Padahal di sekitar kita banyak sekali katalis herbal yang mampu menyembuhkan sembelit tanpa mengeluarkan banyak biaya. Salah satunya adalah buah tomat(18). Buah tomat sangat mudah dijumpai di Indonesia, khususnya di daerah kita Sumatera Barat.

Tomat merupakan salah satu jenis sayuran yang sangat familiar di kalangan kita. Tomat bahkan dengan mudah dibudidayakan di daerah Sumatera Barat ini, mengingat daerahnya yang kebanyakan merupakan dataran tinggj(19). Dari tanaman tomat yang sering di ambil adalah buahnya. Buah tomat sering dijadikan sebagai pencampur dalam membuat sambal atau sebagai penyedap dalam berbagai masakan daerah, bahkan dijadikan sebagai jus. Tomat sendiri berasal dari Amerika Selatan dan Tengah(20). Tumbuhan tomat memiliki nama latin Solanum lycopersicum syn Lycopersicum esculentum. Tumbuhan tomat merupakan tumbuhan yang tubuh dengan umur yang bisa dikatakan pendek(21). Di mana tumbuhan ini dapat hidup sampai 3-4 bulan dengan tinggj 1 sampai dengan 3 meter(22). Batang, daun, dan akarnya tak dapat di konsumsi karena mengandung alkaloid yang berasa pahit. Oleh karena itu, yang di konsumsi hanyalah buahnya(23)

Berdasarkan informasi yang didapatkan dari berbagai kalangan, buah tomat yang sudah matang atau telah merah dapat menyembuhkan sembelit(24). Maka dari itu, tujuan dari penelitian ini adalah menganalisis ekstrak buah tomat pada reaksi katalitik dalam penyembuhan sembelit.

\section{Metode}

\section{Alat dan bahan}

Peralatan yang dipakai dalam penelitian ini adalah sendok (bio) blender (miyako) saringan (tanpa merek) dan gelas(kig indonesia). Bahan yang digunakan adalah buah tomat dari parak Ladang Laweh

\section{Prosedur kerja}

1. Penyiapan sampel

Sampel di ambil dari Parak Ladang Laweh sebanyak 1 kilo gram. Kemudian di cuci di bawah air yang mengalir.

2. Pembuatan ekstrak

Sampel yang telah disediakan kemudian di ambil sebanyak 250 gram dan di masukkan ke dalam blender untuk dihaluskan. Setelah halus sampel di saring untuk di ambil ekstraknya 
menggunakan saringan yang telah dibersihkan terlebih dahulu. Sampel disaring ke dalam sebuah gelas sebanyak $200 \mathrm{~mL}$.

3. Pengujian ekstrak

Sampel yang telah di ambil ekstraknya sebanyak $200 \mathrm{~mL}$ di minum sekali sehari sebelum tidur selama 3 hari kepada penderita sembelit. Dan melihat hasilnya di pagi hari.

Metode ini dapat dibuat dengan diagram sebagai berikut :

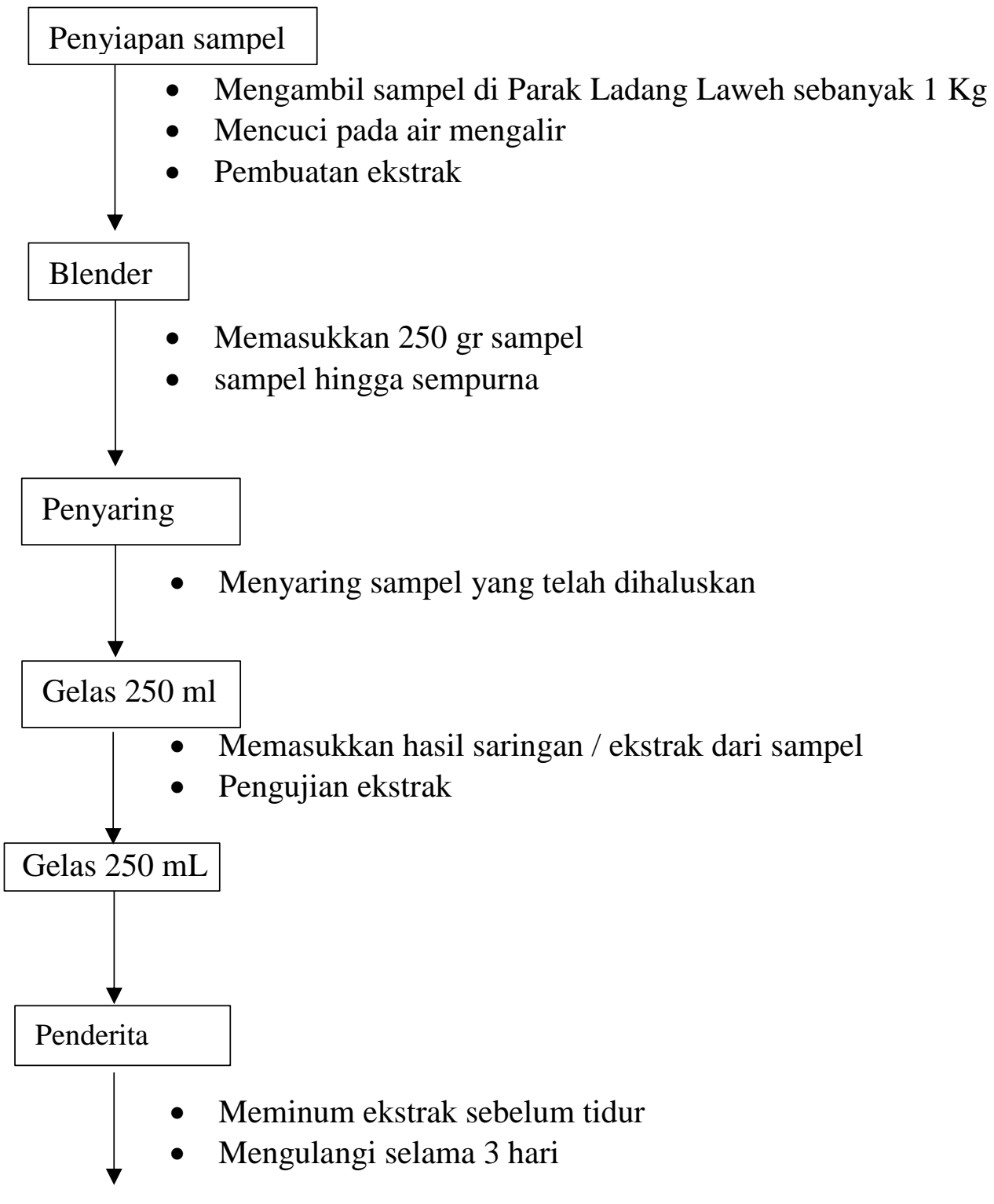

Melakukan pengujian dengan variasi 2 kali sehari yaitu pada pagi dan sore hari serta 3 kali sehari setelah makan

\section{Hasil dan Pembahasan}

\section{Hasil}

Hasil pembuatan ekstrak diperoleh sebanyak $200 \mathrm{~mL}$ dari $1 / 4 \mathrm{Kg}$ dalam sekali ekstraksi . Hal ini dapat dilihat pada gambar berikut : 


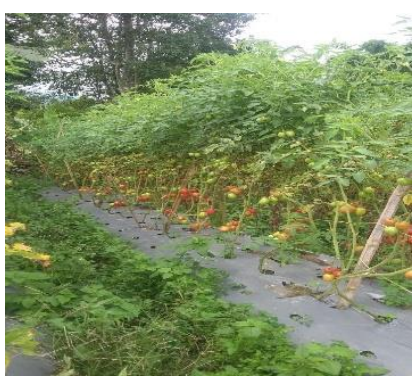

Pengambilan sampel

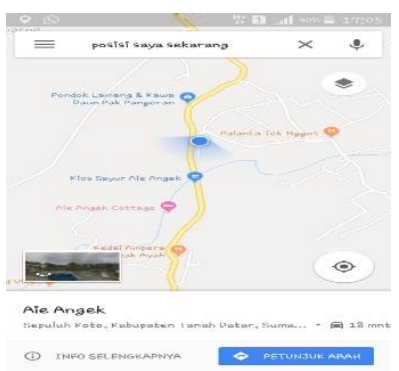

lokasi pengambilan

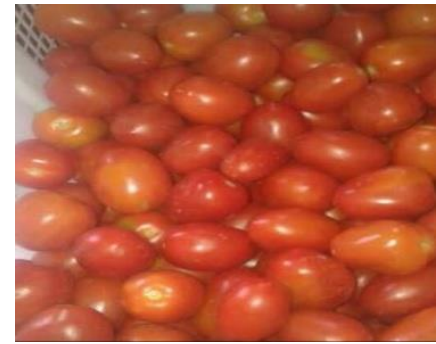

buah tomat

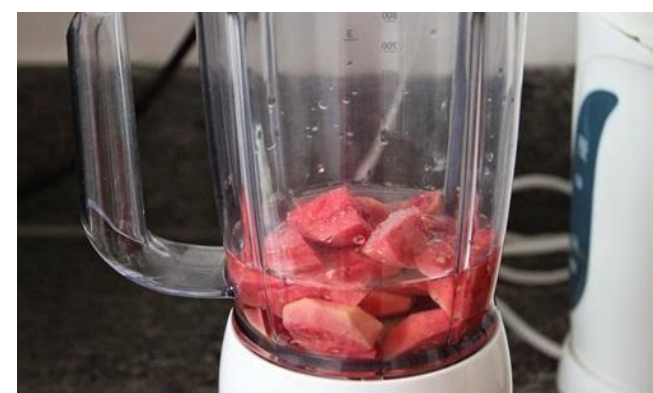

Penghalusan sampel

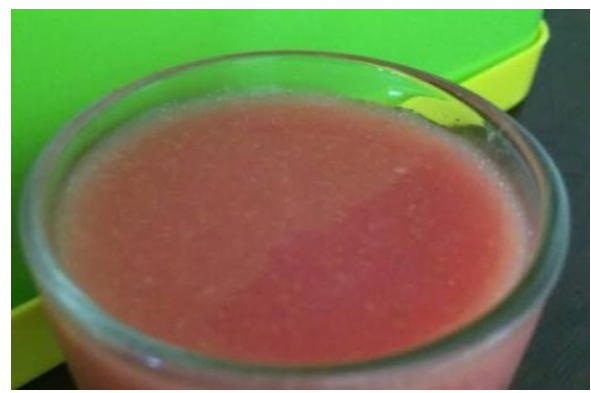

ekstrak yang didapatkan

Pengujian dilakukan terhadap penderita sembelit ternyata berhasil. Dapat dilihat berdasarkan Tabel di bawah ini.

\begin{tabular}{|l|l|l|}
\hline NO & $\begin{array}{l}\text { VARIASI } \\
\text { PEMAKAIAN } \\
\text { SELAMA 3 HARI }\end{array}$ & $\begin{array}{l}\text { HASIL SETELAH 3 } \\
\text { HARI }\end{array}$ \\
\hline 1 & 1 (sebelum tidur) & $\begin{array}{l}\text { Agak Lancar (BAB 1 X } \\
2 \text { hari) }\end{array}$ \\
\hline 2 & 2 (pagi dan sore) & $\begin{array}{l}\text { Lancar (BAB 1 X } \\
\text { sehari) }\end{array}$ \\
\hline 3 & 3 (setelah makan) & $\begin{array}{l}\text { Sangat lancar (BAB 2 X } \\
\text { sehari) }\end{array}$ \\
\hline
\end{tabular}

Pengujian ekstrak buah tomat dapat di buat kan dengan grafik seperti di bawah ini.

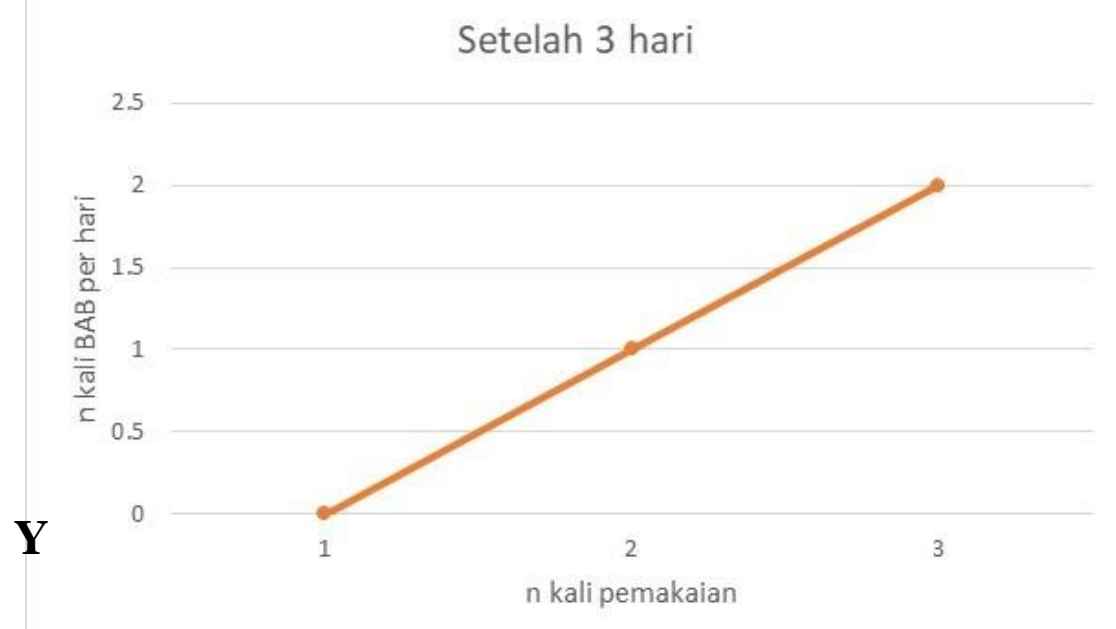




\section{Pembahasan}

Pembuatan katalis herbal dari buah tomat menggunakan metode eksperimen dan uji aktivitas katalitik dilakukan dengan pengambilan ekstrak buah tomat dari Parak Ladang Laweh sebanyak 1 $\mathrm{Kg}$ dapat menghasilkan ekstrak sebanyak $800 \mathrm{~mL}$. Buah tomat yang ambil adalah buah tomat yang sudah matang atau sudah siap petik. Hal ini dikarenakan buah yang sudah matang memiliki serat yang lebih banyak dibandingkan dengan buah yang masih muda atau hijau(25). Pengambilan ekstrak dilakukan dengan teknik penghalusan dan penyaringan. Pemakaian teknik ini dikarenakan ekstrak yang akan diambil dan diuji langsung adalah berupa cairan yang nantinya akan dikonsumsi langsung(26). Pada pengujian aktivitas katalitiknya, sebanyak $200 \mathrm{~mL}$ ekstrak dari buah tomat diminum oleh penderita sembelit dengan variasi sekali sehari yaitu sebelum tidur, dua kali sehari yaitu pagi dan sore hari, dan tiga kali sehari yaitu setelah makan. Pada uji coba ini ternyata ekstrak buah tomat dapat menyembuhkan sembelit yang diderita oleh penderita pada pemakaian optimum 2 kali sehari yaitu pada pagi dan sore hari. Di mana penderita dapat BAB sekali dalam sehari.

Sembuhnya sembelit setelah mengonsumsi ekstrak buah tomat ini dikarenakan adanya aktivitas katalitik yang dilakukan oleh ekstrak buah tomat terhadap sistem pencernaan(27). Buah tomat dapat menyembuhkan sembelit dikarenakan buah tomat mengandung serat yang cukup tinggi(28). Kandungan serat dalam buah tomat inilah yang dapat merangsang gerakan otot-otot usus sehingga dapat melakukan gerakan peristaltik dalam usus dengan baik dalam mencerna makanan (29). Sehingga dengan baiknya gerakan peristaltik pada usus ini, dapat mencerna sisa makanan di dalamnya dengan baik untuk dapat dibuang secara teratur(30). Aktivitas katalitik ini terjadi antara serat dalam ekstrak buah tomat dengan otot-otot usus yang melakukan gerakan peristaltik dalam proses pencernaan(31).

Aktivitas katalitik bekerja secara optimum pada pemakaian 2 kali sehari yaitu pada pagi hari dan sore hari sebanyak $200 \mathrm{~mL}$ dalam sekali minum. Dalam jumlah pemakaian ini menyebabkan buang air besar (BAB) terjadi sebanyak 1 kali dalam sehari. Hal ini membuktikan bahwa penggunaan ekstrak buah tomat dapat menyembuhkan sembelit dan melancarkan proses pencernaan dalam tubuh(32). Namun pemakaian ini tidak boleh dilakukan secara terus menerus setiap harinya. Karna akan menimbulkan efek samping dari pengonsumsian buah tomat secara berlebihan seperti dapat menyebabkan mencret(33). Setelah buang air lancar maka pengonsumsian buah tomat dapat dihentikan dan dapat memperbaiki pola makan dan makanan yang di konsumsi untuk mencegah terjadinya sembelit kembali(34).

Aktivitas katalitik dapat dilihat berdasarkan grafik di bawah ini

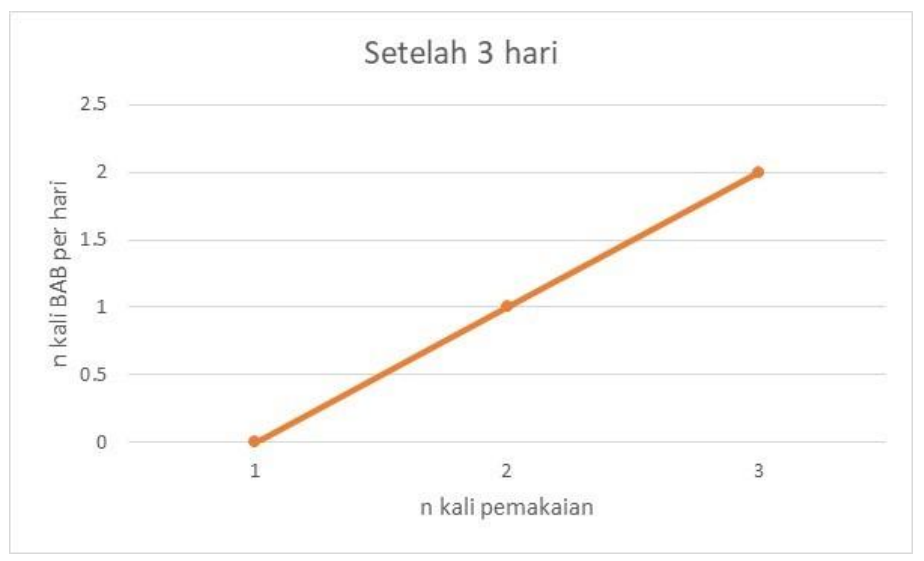


Dari grafik dapat dilihat bahwa dengan bertambahnya jumlah pemakaian ekstrak buah tomat maka buang air besar akan semakin lancar(35).

\section{Kesimpulan}

Ekstrak buah tomat yang dapat di buat dari 250 gram buah tomat sebanyak $250 \mathrm{~mL}$ ekstrak. Ekstrak buah tomat dapat menyembuhkan penyakit sembelit dengan pemakaian selama 3 hari sebanyak 200 $\mathrm{mL}$ dalam pemakaian 2 kali sehari yaitu pada pagi dan sore hari. Ekstrak buah tomat dapat menyembuhkan penyakit sembelit karena mengandung serat yang cukup tinggi di dalamnya. Reaksi katalitik yang terjadi yaitu antara serat buah tomat dengan otot-otot usus yang melakukan gerakan peristaltik.

\section{Referensi}

[1] Megawati, Megawati , Sediawan, Wahyudi Budi,Sulistyo, Hary,Hidayat,Muslikhin.2009 .kinetika reaksi hidrolisis. Reaktor. Vol.12 no.4

[2] Zainul, R., Oktavia, B., \& Dewata, I. efendi, j.2017. Studi Dinamika Molekular dan Kinetika Reaksi pada Pembelahan Molekul Air untuk Produksi Gas Hidrogen.

[3] Ruswandi, R.2018. "Determination of Fructose Content resulted by Inulin Hydrolysis with DNS as Oxidizer”, EKSAKTA: Berkala Ilmiah Bidang MIPA, 19(1), pp. 14-23. doi: 10.24036/eksakta/vol19-iss1/102.

[4] Zainul, R.2018. Effect of Temperature and Particle Motion against the ability of ZnO Semiconductor Photocatalyst in Humic Acid. https://doi.org/10.31227/osf.io/wnygb

[5] Azwir Anhar, Ramadhan Sumarmin and Rahadian Zainul, 2016, Measurement of glycemic index of West Sumatera local rice genotypes for healthy food selection. Journal of Chemical and Pharmaceutical Research

[6] Zuhrina Masyithah, Sola FideGavra Tarigan, Deviana C.S. Sinaga,2016. EKSTRAKSI LIKOPEN DARI BUAH TOMAT (LycopersicumEsculentum) MENGGUNAKAN PELARUT TUNGGAL DENGAN METODE KRISTALISASI ANTISOLVENT. Jurnal teknik usu

[7] Susanti, N. M. P., Dewi, L. P. M. K., Widjaja, I N.K., Wirasuta, I.M.A.G., Gityarani, K. G.2016. EKSTRAKSI LIKOPEN DARI LIMBAH BUAH TOMAT (Solanumlycopersicum L.). Jurnal farmasi udayana. Vol.5 no.1.

[8] Sari, Diana Permata , Purwarianti, Ayu.2014. EKSTRAKSI KATA KUNCI OTOMATIS UNTUK DOKUMEN BAHASA INDONESIA STUDI KASUS: ARTIKEL JURNAL ILMIAH KOLEKSI PDII LIPI. Jurnal dokumentasi dan informatika.vol.35 no.2

[9] Hidayani, T. 2018. "GRAFTING POLIPROPILENA DENGAN MALEAT ANHIDRIDA SEBAGAI PENGIKAT SILANG DENGAN INISIATOR BENZOIL PEROKSIDA”, EKSAKTA: Berkala Ilmiah Bidang MIPA, 19(1), pp. 56-62. doi: 10.24036/eksakta/vol19-iss1/127.

[10] Sanjaya, H. 2018. “DEGRADASI METIL VIOLET MENGGUNAKAN KATALIS ZnO-TiO2 SECARA FOTOSONOLISIS”, EKSAKTA: Berkala Ilmiah Bidang MIPA, 19(1), pp. 91-99. doi: 10.24036/eksakta/vol19-iss1/131. 
[11] Liza, Y. M., Yasin, R. C., Maidani, S. S., \& Zainul, R. (2018, October 9). SOL GEL : PRINCIPLE AND TECHNIQUE (A REVIEW). https://doi.org/10.31227/osf.io/2cuh8

[12] Chaidir, Z., Zainul, R., Nurakhbari, D., \& Salim, M. 2016. Optimization of Spirulina Platensis Culture for Antioxidant Production.

[13] Sari, A. 2017. "POTENSI ANTIOKSIDAN ALAMI PADA EKSTRAK DAUN JAMBLANG

(Syzigium cumini (L.) Skeels)”, EKSAKTA: Berkala Ilmiah Bidang MIPA, 18(02), pp. 107-112. doi: 10.24036/eksakta/vol18-iss02/61.

[14] Kusumawardhani, Amalia, Widodo, Winarso Drajad.2003. Pemanfaatan Pupuk Majemuk sebagai Sumber Hara Budidaya Tomat secara Hidroponik. Jurnal agronomi indonesia. Vol.31 no.1 [15] Nurfadilah, K. K., \& Zainul, R. (2019, February 3). Kalium Nitrat (KNO3): Karakteristik Senyawa dan Transpor Ion. https://doi.org/10.31227/osf.io/dr8ef

[16] Zainul, R. (2018, August 16). Design and Modification of Copper Oxide Electrodes for Improving Conversion Coefficient Indoors Lights (PV-Cell) Photocells. https://doi.org/10.31227/osf.io/pgn84

[17] Iswari, K.2015. Pemanfaatan Tomat dan Sirsak sebagai Bahan Dasar Pembuatan Produk Suplemen Kesehatan. Jurnal holtikultura. Vol.25 no.4

[18] Huda, N. (2017) "PENGARUH EKSTRAK SAMBILOTO (Andrographis paniculata Nees.) TERHADAP SIKLUS ESTRUS MENCIT (Mus musculus L. Swiss Webster)”, EKSAKTA: Berkala Ilmiah Bidang MIPA, 18(02), pp. 69-76. doi: 10.24036/eksakta/vol18-iss02/55.

[19] Hakimi, A., \& Zainul, R. (2019, January 31). Asam Arsenat (H3AsO4) : Analisis Molekular dan Karakteristik Senyawa. https://doi.org/10.31227/osf.io/e486z

[20] Dinata, A. A., Rosyadi, A. M., Hamid, S., \& Zainul, R. (2018, October 15). A Review CHEMICAL VAPOR DEPOSITION : PROCESS AND APPLICATION.

https://doi.org/10.31227/osf.io/yfeau

[21] Arifulloh, Arifulloh, Oktavianawati, Ika, Adi Winata, I Nyoman.2016. EKSTRAKSI LIKOPEN DARI BUAH TOMAT (LYCOPERSICUM ESCULENTUM MILL.) DENGAN BERBAGAI KOMPOSISI PELARUT. Berskala sainstek. Vol.4 no.1

[22] Rizki Saputra, M. and Sumarmin, R. (2018) "PENGARUH EKSTRAK DAUN SIRIH MERAH

(Piper crocatum Ruiz \& Pav.) TERHADAP GLUKOSA DARAH MENCIT (Mus musculus L.)

JANTAN YANG DIINDUKSI SUKROSA”, EKSAKTA: Berkala Ilmiah Bidang MIPA, 19(1), pp. 43-

55. doi: 10.24036/eksakta/vol19-iss1/124.

[23].Horiza, H., Azhar, M. and Efendi, J. (2017) "EKSTRAKSI DAN KARAKTERISASI INULIN

DARI UMBI DAHLIA (Dahlia sp.L) SEGAR DAN DISIMPAN”, EKSAKTA: Berkala Ilmiah Bidang MIPA, 18(01), pp. 31-39. doi: 10.24036/eksakta/vol18-iss01/14.

[24. Warlinda, Y. A., \& Zainul, R. (2019, January 29). Asam Posfat (H3PO4): Ionic Transformation of Phosphoric Acid in Aqueous Solution. https://doi.org/10.31227/osf.io/s3y8v

[25].Ningsih, S. K. (2017) "SINTESIS DAN KARAKTERISASI NANOPARTIKEL ZnO DOPED Cu2+ MELALUI METODA SOL-GEL", EKSAKTA: Berkala Ilmiah Bidang MIPA, 18(02), pp. 3951. doi: 10.24036/eksakta/vol18-iss02/51.

[26] Kristy, D. P., \& Zainul, R. (2019, February 3). Analisis Molekular dan Transpor Ion Natrium Silikat. https://doi.org/10.31227/osf.io/8ac4m 
[27] Sumarmin, R. (2018) "Pengaruh Ekstrak Kulit Buah Manggis (Garcinia mangostana L.) terhadap Histologis Pankreas Mencit (Mus musculus L. Swiss Webster) yang Diinduksi Sukrosa”, EKSAKTA: Berkala Ilmiah Bidang MIPA, 19(1), pp. 100-112. doi: 10.24036/eksakta/vol19-iss1/123.

[28] Sanjaya, H. (2017) “DEGRADASI METHYLENE BLUE MENGGUNAKAN KATALIS ZnOPEG DENGAN METODE FOTOSONOLISIS”, EKSAKTA: Berkala Ilmiah Bidang MIPA, 18(02), pp. 21-29. doi: 10.24036/eksakta/vol18-iss02/45.

[29] GUNARTA, I WAYAN, RAKA, I GUSTI NGURAH,ASTININGSIH, A.A.M.2014. Uji Efektivitas Beberapa Teknik Ekstraksi dan DryHeatTreatment terhadap Viabilitas Benih Tomat (LycopersicumesculentumMill.). JournalofTropicalAgroecotechnology. Vol.3 no.3 [30] Liza, Y. M., Yasin, R. C., Maidani, S. S., \& Zainul, R. (2018, October 9). SOL GEL : PRINCIPLE AND TECHNIQUE (A REVIEW). https://doi.org/10.31227/osf.io/2cuh8

[31] Putri, D. F., Ritonga, H. M., Murdiati, V., \& Zainul, R. (2018, October 15). A REVIEW WHAT IS HYDROTHERMAL ?. https://doi.org/10.31227/osf.io/dm56c

[32] Ernawati,., Suryanti, Rahmawati, Intan Dyah.2014. PENGARUH STATIK KONTRAKSI TERHADAP KECEPATAN KEMBALINYA PERISTALTIK USUS PADA PASIEN POST SECTIO CAESAREA (SC). Jurnal bidan prada. Vol.5 nol.1

[33] Zainul, R., Alif, A., Aziz, H., Arief, S., \& s. (2018, August 16). Photoelectrosplitting Water Mechanism at Carbon Electrode Surface using Indoor lights. https://doi.org/10.31227/osf.io/vcxq8

[34] Lubis, A. P., \& Zainul, R. (2018, November 5). Interaksi Molekuler Amonium Hidroksida. https://doi.org/10.31227/osf.io/jht3b

[35] Maryanto, Luthfi Eka, Basyirun, Basyirun, Anis, Samsudin.2018. PENGARUH DIAMETER ROLLER TERHADAP DEBIT POMPA PERISTALTIK. Sainteknol. Vol.16 no.1 